\title{
RESPON DAN PARTISIPASI MASYARAKAT \\ TERHADAP PENGELOLAAN PENDIDIKAN ISLAM NONFORMAL DI MAJLIS \\ TAKLIM PENDIDIKAN PASCA TPQ QIRAATI YPI "SHIDQUL AMAL" KEDUNGJAYA KEDAWUNG KABUPATEN CIREBON
}

\section{Taqiyuddin}

\author{
DosenManajemenPendidikan Islam \\ FITK IAIN Syekhnurjati Cirebon \\ Email:ataqiyudin@gmail.co.id
}

\begin{abstract}
ABSTRAK
Lembaga-lembaga pendidikan Islam yang ada di YPI "Shidqul Amal" Desa Kedungjaya Kecamatan Kedawung Kabupaten Cirebon, dapat dikategorikan sebagai bentuk atau jenis pendidikan nonformal yang dalam penyelenggaraan pendidikannya harus dikelola berdasarkan peraturan dan perundang undangan yang berlaku, di antara peraturan itu adalah PP No. 19 tahun 2005 tentang Standar Nasional Pendidikan (SNP). Kegiatan ngaji sore yang dilaksanakan Majelis Taklim Pendi-dikan Pasca TPQ Qiraati merupakan salah satu bentuk kegiatan keagamaan yang ada di YPI "Shidqul Amal" Kedung jaya, dalam pengelolaannya sebagian besar telah sesuai dengan PP No. 19 tahun 2005. Namun berdasarkan pengamatan, masih ada beberapa komponen yang perlu dioptimalkan, di antaranya yaitu pengelolaan yang belum sepenuhnya menggunakan system manajemen pendidikan, kualifikasi tenaga kependidikan dan tenaga pendidik, kurikulum yang digunakan, begitu juga dengan proses pembelajaran.hal tersebut dilakukan para manager adalah karena tujuan lembaga pendidikan tidak akan segera terwujud sesuai dengan apa yang telah direncanakan dan dirumuskan, melainkan harus melakukan pengkajian terhadap kekuatan dan kelemahan, peluang dan ancaman sumber-sumber pendidikan terlebih dahulu.
\end{abstract}

\section{Kata Kunci: Pengelolaan Pendidikan Islam, Respon dan Partisipasi}

\section{A. Pendahuluan}

Pendidikan, bagi masyarakat muslim, merupakan proses tanpa akhir selama hidupnya (long life education). Atas dasar inilah sehingga berbagai bentuk dan jenis pendidikan Islam berdiri di berbagai daerah, sebagai upaya memediasi dan menyebar luaskan ajaran Islam kepada masyarakat melalui berbagai tingkatan. Melalui lembaga-lembaga pendidikan Islam itu, masyarakat Indonesia dapat memahami, menghayati dan mengamalkan ajaran Islam sesuai ketentuan yang ada di dalam al-Qur'an dan al-Sunnah.
Lembaga-lembaga pendidikan Islam itu, di dalam UU RI No. 20 tahun 2003 tentang Sistem Pendidikan Nasional pasal 30 dapat dikategorikan sebagai Pendidikan Keagamaan.

(1) Pendidikan keagamaan diselenggarakan oleh pemerintah dan/atau kelom-pok masyarakat,

(3) Pendidikan keagamaan diselenggarakan pada jalur pendidikan formal, nonformal dan informal,

(4) Pendidikan keagamaan berbentuk ajaran diniyah, pondok pesantren. 
(5) Ketentuan mengenai pendidikan keagamaan diatur lebih lanjut dengan peraturan pemerintah

Peraturan Pemerintah nomor 55 tahun 2007 tentang Pendidikan Agama dan Keagamaan, pada pasal 22 disebutkan bahwa "Pendidikan Diniyah Nonformal diselenggarakan dalam bentuk Pengajian kitab kuning (KK), Majelis Taklim, Pendidikan Al-Qur'an, Madrasah Diniyah Takmiliyah, atau bentuk lain yang sejenis". Lembaga pendidikan keagamaan (madrasah diniyah) Islam yang ada di tengah-tengah masyarakat diselenggarakan dalam bentuk pendidikan formal adalah, MI, MTs, MA dan UIN/ IAIN/STAIN. Sedangkan lembaga pendidikan keagamaan yang diselenggarakan dalam bentuk pendidikan nonformal adalah RA, TKQ dan TPQ, madrasah diniyah, Majlis Ta'lim, dan Pondok Pesantren.

Mekanisme prosesnya, dimulai sejak adanya input (peserta didik) yang akan dikelola oleh tenaga kependidikan sesuai pentahapan. Pada tahap akhir, akan diperoleh hasil (output) sebagai sebabakibat dari proses pendidikan. Pentahapan yang dilakukan oleh pembimbing selama proses pembimbingan, diawali dengan tahap belajar mengetahui (learning to know); dilanjutkan dengan tahap berikutnya yaitu belajar mengerjakan (learning to do) atau membuktikan hasil dari sesuatu yang telah dike-tahuinya; tahap berikutnya adalah memperkenalkan kepada orang lain di lingkungan sekitarnya dari apa yang telah diketahui dan dibuktikannya itu melalui learning to life together; tahap akhir yaitu mengembangkan pengetahuan yang telah dibukti-kannya itu sehingga menjadi sesuatu yang telah dimilikinya melalui learning to be. Pada tahap ter-akhir itu, agar sesuatu yang teklah dimiliki seseorang (peserta didik) harus ada respons dan parti-sipasi dari orangtua dan lingkungan masyarakat agar tahapan-tahapan yang telah dialui dalam pro-ses pembimbingan itu hasilnya optimal.
Pernyataan tersebut menggambarkan bahwa, lingkungan keluarga dan masyarakat merupakan tempat atau lembaga (institution) terjadinya proses pembimbingan dan sangat berpengaruh terhadap pertumbuhan fisik dan perkembangan pemikiran terbimbing. Karena itu, dalam merancang dan menentukan proses pendidikan, faktor lingkungan sa-ngat strategis dan menentukan. Tanpa memahami keberadaan lingkungan dengan baik, maka pengelola pendidikan akan menghadapi berbagai persoalan kemasyarakatan dan dapat menghambat tujuan pendidikan. Mengingat pentingnya pengaruh lingkungan masyarakat terhadap proses perkembangan ter-bimbing, maka pengelola pendidikan harus memahami betul latar belakang sikap dan sifat terbimbing dan lingkungannya terlebih dahulu.

Dalam perkembangan berikutnya, suatu lembaga pendidikan di dalamnya terdiri dari beberapa komponen pendidikan sehingga terwujud menjadi sebuah sistem (a system) yaitu sistem pendidikan. Di dalam sistem pendidikan, tidak hanya konpleks tapi juga dinamis, hal ini karena kegiatan inti dari sistem pendidikan adalah mengelola sumber-sumber pendidikan. Untuk mengelolanya secara maksimal, diperlukan sistem pengelolaan (managerial) yang baik, sehingga diharapkan akan ter-wujud dengan mudah tujuan lembaga pendidikan secara efektif dan efisien. Ini artinya, lembaga pendidikan sangat membutuhkan "alat bantu" yang dapat mempermudah pekerjaan instituti dalam merangkai program kegiatan dengan pola keter-aturan dan reabilitas yang tinggi dan mempercepat tercapainya tujuan lembaga pendidikan. Salah satu dari alat bantu itu adalah manajemen atau pengelolaan pendidikan. Dengan kalimat lain, mana-jemen pendidikan harus dijadikan sebagai suatu kesadaran bagi semua pengelola lembaga pendidikan dalam memajukan lembaga-lembaga pendidikan. 
Pada prakteknya, beberapa pengelola lembaga pendidikan telah berusaha memanage lemba-ganya dengan mempelajari dan memahami situasi dan kondisi yang ada di sekitarnya. Ini dilakukan karena tujuan manajemen pendidikan tidak akan segera terwujud sesuai harapan, melainkan harus melakukan pengkajian terhadap kekuatan dan kelemahan, peluang dan ancaman sumber-sumber pendidikan yang telah ada. Selain itu, pengelola juga harus mampu memadukan antara konsep dan teori manajemen dengan fenomena sosiopolitik, sosio-kultural, sosio-ekonomik dan sosio-religius yang terjadi di beberapa lembaga pendidikan lain, agar kaidahkaidah manajerial yang dirumuskannya benar-benar dapat diterapkan.

Hal terpenting lain yang harus dilakukan oleh manajer atau a leader adalah memperhatikan falsafah manajemen pendidikan Islam yang bersumber dari wahyu Allah dan sunah rasulNya. Lembaga pendidikan sebagai a system, tidak cukup hanya usaha keras yang dilakukan oleh seorang pemimpin lembaga pendidikan yakni manager atau kepala lembaga. Sebagai sebuah sistem, kerja keras seorang kepala lembaga pendidikan harus dibantu oleh sumber-sumber pendidikan lain yang telah ada dan memperoleh dukungan dari lingkungan terdekatnya yaitu orang tua dan masyarakat.

Masyarakat Desa Kedungjaya Kecamatan Kedawung Kabupaten Cirebon, diamati dari kondisi latar belakang kehidupan ekonominya, sebagian besar dari mereka adalah bermata pencaharian sebagai pedagang. Sebagai suatu komunitas masyarakat pedagang, mereka memiliki keunikan tersendiri jika dipelajari dari segi sosial-ekonomi, dan tradisi budayanya. Sehingga kondisi pendidikan anak-anaknya juga sangat dipengaruhi oleh latar belakang kehidupan dan pendidikan orang tuanya.

Dalam kontek pendidikan anak, kehidupan masyarakat Kedung jaya seperti itu tidak memungkinkan anak-anak lakilaki untuk melanjutkan pendidikannya ke jenjang pendidikan yang lebih tinggi. Sudah menjadi pandangan umum bahwa, ketika anak laki-laki telah lulus dari jenjang Pendidikan Dasar 9 tahun (SD/MISMP/MTs), mereka diikutsertakan oleh orangtuanya untuk mencari nafkah membantu orang tuanya berdagang. Karena itu tidak salah jika ada sebagian masyarakat yang beranggapan bahwa, masyarakat pedagang seringkali diasumsikan sebagai masyarakat yang kurang mak-simal dalam memperhatikan masa depan pendidikan anaknya.

Masyarakat Kedungjaya memiliki konsep dan pemahaman tersendiri tentang pendidikan, kesejahteran, dan kesehatan yang secara turun temurun diwariskan kepada anak-anaknya sebagai menunjang potensi dan kreatifitas hidup masa depannya. Sebagian masyarakat Kedungjaya berpandangan bahwa, pendidikan anak laki-lakinya yang penting sudah mampu membaca, menulis dan terutama berhitung, setelah itu mereka sudah harus dilatih menjadi orang yang mandiri dan bertanggung jawab sebagai laki-laki yaitu mencari nafkah. Tapi, sebagai sebuah komunitas masyarakat yang hidup di tengah-tengah komunitas lain yang lebih luas, cara pandang dan harapan hidup mereka terhadap masa depan anak-anaknya harus sejalan dengan cara pandang hidup masyarakat lainnya. Untuk itu yang harus dilakukan setiap orangtua/masyarakat Kedungjaya adalah memadukan paradigma hidupnya dengan kondisi aktual dan faktual masyarakat luas yang ada di lingkungannya.

Atas dasar itulah maka cukup beralasan jika ada pandangan bahwa bagi masyarakat seperti masyarakat Kedungjaya perlu dicarikan bentuk dan jenis pendidikan yang sesuai dengan kondisi dan kebutuhan kehidupan mereka. Salah satu konsep pendidikan yang dapat ditawarkan adalah konsep pendidikan berbasis masyarakat yang mengacu kepada konsep pemberdayaan (empowering), yakni bagaimana memberikan pemahaman agar 
masyarakat Kedungjaya memiliki kesadaran tentang penting dan perlunya masa depan pendidikan anak-anaknya dengan tanpa mengurangi keterlibatan anaknya dalam membantu ekonomi orang tuanya.

Di tengah-tengah komunitas masyarakat Kedungjaya yang mayoritas bermata pencahariaannya sebagai pedagang itu, ada seseorang yang oleh masyarakatnya dipercaya sebagai pemuka agama (a leader nonformal), ialah KH. Abu Khaeruddin Thohir. Beliau sejak tahun 2008 berusaha keras membangun dan memberikan pandangan hidup kepada masyarakat Kedungjaya dan sekitarnya tentang pentingnya masa depan pendidikan bagi anak-anak. Berdasarkan hasil wawancara dengan KH. Abu Khaeruddin Thohir dan pengamatan terhadap kehidupan masyarakat Kedung jaya, diperoleh gambaran bahwa peran awal yang dilakukannya adalah, menanamkan nilainilai agama dan moralitas masyarakat melalui kegiatan ngaji quran dan dasardasar ajaran Islam kepada anak-anak dan remaja di lingkungan rumahnya. Saat itu, kegiatan keagamaan ini dilaksanakan dalam bentuk ngaji sore, karena kegiatan ini diselenggarakan pada antara jam 18.30 sampai dengan 20.30 bertempat di rumahnya.

Saat wawancara dan observasi dilakukan, April 2016, kegiatan ngaji sore sudah berkembang pesat layaknya sistem pendidikan keagamaan atau madrasah diniyah yaitu muridnya terdaftar, terdata dan terdokumentasi, pengajaran yang dilakukan ustadz juga terjadwal sesuai dengan bidang ilmu dan materi ajarnya, tempat belajarnya sebagian murid belajarnya di madrasah diniyah dan sebagian murid lainnya belajar di mushalla yang tempatnya masih dalam satu komplek. Kedua bentuk tempat belajar itu, berada dalam satu atap sebagai bentuk-bentuk pendidikan yang ada di Yayasan Pendidikan Islam (YPI) "Shidqul Amal" Kedungjaya.
Pada saat yang bersamaan, paradigma atau cara pandang masyarakat Kedung jaya terhadap massa depan pendidikan anaknya telah mengalami perubahan dan pergeseran. Kondisi ekonomi, sosial dan budaya turut mewarnai perubahan paradigma ini, bahkan status sosial tidak lagi mempengaruhi beberapa keluarga masyarakat pedagang itu terhadap rasa tanggung jawabnya sebagai orangtua dalam memperhatikan masa depan pendidikan al-Quran anak-anaknya.

Hasil pengamatan terhadap perubahan paradigma yang terjadi pada masyarakat Kedungjaya itu, ditemukan paling tidak ada empat faktor yaitu

1. Perkembangan jaman, sebagai dampak positif dari pemberitaan media masa elektro (TVRI maupun TV Swasta),

2. Kebijakan Pemerintah RI tentang Wajib Be-lajar (Wajar) 9 tahun melalui Pendidikan Dasar 9 tahun,

3. Perubahan status sosial dari masyarakat pe-dagang yang rendah pendidikannya menjadi masyarakat terdidik,

4. Hasil usaha keras yang dilakuan $a$ leader non formal melalui ngaji sore-nya itu dilaksanakan di Majlis Taklim Pendidikan Pasca TPQ Qiraati yang berada di YPI "Shidqul Amal" Kedungjaya

Dari keempat faktor penyebab perubahan paradigma tersebut di atas, penelitian ini secara khusus akan mendalami hasil usaha keras a leader nonformal melalui kegiatan ngaji sore yang dilaksanakan di Majlis Taklim Pendidikan Pasca TPQ Qiraati yang ada di YPI "Shidqul Amal" Kedung jaya. Tujuan utamanya yaitu memotret keberadaan pengelolaan kegiatan ngaji sore sebagai bahan evaluasi terhadap kemajuan lembaga pendidikan nonformal itu. Ada tiga alasan mendasar mengapa peneliti tertarik untuk mengadakan penelitian ten-tang sistem pengelolaan pendidikan nonformal di Kedungjaya itu, yaitu: 
Pertama, secara historis kegiatan ngaji sore merupakan bagian dari system pendidikan pesantren. Sementara pendidikan pesantren sendiri adalah salah satu bentuk pendidikan Islam tertua di Indonesia, tetapi perkembangan berikutnya setelah muncul beberapa bentuk dan jenis pendidikan Islam berbentuk kegiatan keagamaan lain, keber-adaan ngaji sore semakin jauh tertinggal.

Kedua, secara faktual minat masyarakat terhadap kegiatan ngaji sore sudah mulai mengalami perubahan orientasi; masyarakat yang mendaftarkan anak-anaknya yang belajar dan mengikuti kegiatan ngaji sore tidak lagi menjadikan kegiatan ngaji sore sebagai pilihan utama bagi anak-anaknya untuk mempelajari alQuran dan dasar-dasar ajaran islam, melainkan karena merasa khawatir terhadap masa depan kehidupan anaknya terkena dampak negatif dari pergaulan bebas.

Ketiga, penelitian ini dilakukan di tempat kegiatan ngaji sore yang dilaksanakan di Majlis Taklim Pendidikan Pasca TPQ Qiraati yang ada di YPI "Shidqul Amal" Kedungjaya. Berdasarkan hasil wawancara dan pengamatan awal, diperoleh gambaran bahwa secara historis masyarakat Kedungjaya telah mengenal kegiatan ngaji sore begitu kegiatan ini diselenggarakan oleh $\mathrm{KH} \mathrm{Abu}$ Khaeruddin Thohir pada tahun 2008, terlihat dari beberapa keluarga yang menyuruh anakanaknya untuk mengikuti kegiatan ngaji sore.

Atas dasar itulah peneliti berpandangan bahwa, sistem pendidikan Islam yang ada di YPI "Shidqul Amal" Kedungjaya masih belum dikelola sebagaimana penge-lolaan lembaga pendidikan Islam pada umumnya. Karena itu, melalui penelitian ini diharapkan akan diperoleh gambaran lebih mendalam tentang Respon dan Partisipasi Masyarakat terhadap Pengelolaan Pendidikan Islam Nonformal Studi Kasus Kegiat-an KH Abu Khaeruddin Thohir melalui Ngaji Sore di Majlis Taklim Pendidikan Pasca TPQ
Qiraati Yayasan Pendidikan Islam (YPI) "Shidqul Amal" Kedung jaya Kecamatan Kedawung Kabupaten Cirebon.

\section{B. Kerangka Teoritis \\ 1. Pendidikan Islam Nonformal}

Undang-undang Nomor 20 Tahun 2003 tentang Sistem Pendidikan Nasional menyebutkan, pendidikan nonformal (PNF) didefinisikan sebagai jalur pendidikan di luar pendidikan formal tapi dapat dilaksanakan secara terstruktur dan berjenjang. Fungsi pendidikan nonformal (PNF) yaitu mengembangkan potensi peserta didik dengan penekanan pada penguasaan pengetahuan dan keterampilan fung-sional serta pengembangan sikap dan kepribadian profesional. Satuan pendidikan PNF meliputi PKBM, lembaga pelatihan, dan lembaga-lembaga pendidikan keagamaan yang termasuk kategori PNF antara lain Pesantren; madrasah diniyah, RA, TKQ\&TPQ dan Majlis Taklim. Lulusan PNF, setara dengan hasil program pendidikan formal, setelah melalui proses penilaian oleh lembaga yang ditunjuk Pemerintah atau Pemerintah Daerah.

Lembaga atau organisasi pendidikan, merupakan suatu wadah atau tempat terjadinya proses pembelajaran. Untuk mengelola proses pembelajaran secara maksimal, diperlukan sistem managerial yang baik dengan harapan akan terwujudnya tujuan lembaga pendidikan yang efektif, efisien, dan tercapainya tujuan pembelajaran yang optimal. Manajemen pendidikan Islam menurut Mujamil Qomar (2008:10) adalah suatu proses pengelolaan lembaga pendidikan Islam secara Islami dengan cara menyiasati sumber-sumber belajar dan hal-hal yang terkait untuk mencapai tujuan pendidikan Islam secara efektif dan efisien.

Pengelolaan pendidikan Islam dalam penelitian ini adalah pengelolaan lembaga pendidikan Islam nonformal yakni Majlis Taklim (MT). Majlis taklim (MT) secara lughawi berarti "suatu tempat yang digunakan untuk pelaksanaan pengajaran atau pengajian dasar-dasar agama Islam" 
(Taqiyuddin, 2008). Sedangkan secara istilahi, MT merupakan suatu lembaga pendidikan Islam nonformal, yang fungsi dan tujuan keberadaannya untuk menyebarkan ajaran Islam kepada masyarakat luas. Dalam perkembangan berikutnya, istilah MT tidak hanya terbatas pada suatu tempat untuk belajar, tetapi menjadi suatu lembaga yang dapat dijadikan sebagai sarana yang sangat efektif dan efisien dalam mengeducaty masyarakat. Di beberapa daerah, keberadaan MT tidak hanya dijadikan sebagai sarana silaturahmi atau interaksi keagamaan antar masyarakat (sosioreigius), melainkan sosio-ekonomi, sosiocultur dan sosio-politik pun kerap terjadi di MT. Karena di dalam MT kerap kali terjadi proses pembelajaran sebagai perwujudan dari kegiatan keagamaan, sedangkan materi yang disampaikan di MT lebih dominan masalah perbaikan akhlaq (tahsin alkhuluq), maka membicarakan MT tidak bisa lepas dari pembahasan tentang ajaran Islam khususnya masalah akhlaq. Diwajibkan bagi orang yang mau tahsin alkhuluq adalah memiliki kemampuan membaca dan menghafal ayat-ayat alQuran, kemudian memahami dan mengamalkan isi kandungan ayat-ayat aQuran itu.

\section{Respon dan Partisipasi Masyarakat}

Istilah respons (Bahasa Inggris) berarti "tanggapan", "reaksi" dan "jawaban". Proses respon dalam bentuk reaksi, akan muncul dari penerimaan pesan setelah terjadinya serangkaian komunikasi (Poerwadarminta, 1999:43). Respon akan muncul dari penerimaan pesan setelah terjadinya serangkaian komunikasi. Dengan adanya respon yang disampaikan komunikan kepada komunikator, akan menetra-lisir kesalahan penafsiran dalam sebuah proses komunikasi (Ahmad Subandi, 1982:50). Secara umum, respon atau tanggapan dapat diartikan sebagai hasil yang didapat dari pengamatan terhadap peris-tiwa atau hubungan- hubungan yang diperoleh dengan menyimpulkan informasi dan menafsirkan pesan-pesan (Jalaludin Rahmat, 1999:51).

Proses terjadinya respon, melalui pengamatan terlebih dahulu terhadap stimulan. Saat itu respon yang muncul, dapat berupa dukungan atau rintangan dari respon lain. Dukungan terhadap respon, ada yang bersifat positif ada juga yang bersifat negatif. Respon yang bersifat positif, cenderung tindakannya mendekati, menyukai, dan menyenangkan. Karena itu, indikator respon yang bersifat positif adalah, menimbulkan perasaan senang (happiness). Berbeda dengan respon yang bersifat negatif yaitu, suatu kecenderungan untuk bertindak menghindari atau menjauhi. Indikatornya adalah, antara lain menimbulkan perasaan tidak senang (unhappy).

Sedangkan istilah partisipasi (participation) artinya keterlibatan mental dan emosional seseorang terhadap pencapaian tujuan dan ikut bertanggung jawab. Secara sederhana, partisipasi dapat diartikan sebagai keikutsertaan seseorang atau sekelompok masyarakat dalam program kegiatan. Paling tidak ada dua alasan utama pentingnya partisipasi, yaitu: a) Partisipasi merupakan salah satu alat untuk memperoleh informasi tentang kondisi, kebutuhan dan tanpa kehadirannya prgram akan gagal, b. Partisipasi merupakan hak demokrasi masyarakat (Conyers, 1991).

Keterlibatan masyarakat sebagai suatu kesatuan, dapat disebut partisipasi kolektif, sedangkan keterlibatan individual dalam kegiatan kelompok dapat disebut partisipasi individual. Partisipasi seperti ini dapat dibedakan menjadi partisipasi vertikal dan horisontal. Parti-sipasi vertikal yaitu, masyarakat terlibat/mengambil bagian pada suatu program masyarakat lainya, sebagai bentuk hubungan antar sesama warga masyarakat. Sedangkan partisipasi horisontal yaitu, setiap kelompok masyarakat berpartisipasi horisontal satu dengan yang lain, baik 
dalam melakukan usaha bersama maupun dalam rangka melakukan kegiatan.

Ketika seseorang atau sekelompok orang berpartisipasi dalam suatu kegiatan, pasti dilandasi oleh motif-motif tertentu. Ada beberapa bentuk partisipasi yang dilakukan orang, antara lain: partisipasi spontanitas yaitu partisipasi yang dilakukan seseorang/ masyarakat secara spontan dalam mengikuti aksi bersama; Fasilitasi yaitu partisipasi yang dilakukan seseorang/masyarakat secara sengaja, dirancang dan didorong oleh masyarakat untuk membantu menyelesaikan masalah bersama; Induksi yaitu partisipasi yang dilakukan seseorang/masyarakat melalui propaganda/ mem-pengaruhi orang lain melalui emosi dan patriotisme; Kooptasi yaitu partisipasi yang dilakukan seseorang/masyarakat untuk memperoleh keuntungan materi.

Adapun bentuk-bentuk partisipasi yang dilakukan orang, antara lain: partisipasi berbentuk gagasan atau ide, disampaikan dalam berbagai pertemuan; partisipasi berbentuk tenaga, diberikan ketika ada perbaikan sarana prasarana; partisipasi berbentuk sosial, diberi-kan sebagai suatu symbol/tanda pada saat keguyuban.

\section{Kerangka Pemikiran}

Kegiatan yang dilakukan oleh kyai sebagai a leader nonformal bersifat keagamaan dalam bentuk ngaji sore yang secara khusus diperuntukan bagi anak pedagang di lingkungan setempat, bukanlah berbentuk kegiatan sebagaimana yang dilakukan di lembaga-lembaga pendidikan formal. Kegiatan ngaji sore yang dilaksanakan $\mathrm{KH}$ Abu Khaeruddin Thohir, dapat dikategorikan sebagai bentuk pedidikan nonformal tetapi dilaksanakan secara formal sebagaimana kegiatan kependidikan di RA ataupun di madrasah dinyah. Hal ini karena dalam proses pembelajaranya telah dilaksanakan secara terprogram yaitu, terencana dan terstruktur melalui jadwal pembelajaran yang tercantum di ruang kelas. Begitu juga pada proses pembelajaran, ustadz menyam-paikan materi ajar sesuai dengan bidang ilmunya, berlangsung di ruangan/kelas yang di hadapan sejumlah murid yang telah siap materi dari ustadznya. Materi ajar yang disampaikan ustadz, sebagaimana yang tercantum dalam jadwal, dimulai pukul 18.30 setelah sebelumnya dilaksanakan shalat fardlu maghrib secara berjamaah. Proses pembelajaran akan berakhir pada pukul 20.30. tapi sebelum murid kembali ke rumahnya masing-masing, mereka dianjurkan ikut shalat fardu Isya secara berjamaah.

Terpenting dari semua hal tersebut di atas adalah, kegiatan ngaji sore yang melayani pendidikan anak itu, telah memperoleh kepercayaan dari masyarakat, dipimpin oleh seorang pemimpin yang berorientasi pada pengembangan pendidikan dan telah memiliki sumbersumber pendidikan yang memadai sebagai pendukung pembelajaran. Dengan demikian dapat dikatakan bahwa, kegiatan ngaji sore yang dilakukan $\mathrm{KH}$ Abu Khaeruddin Thohir di Majlis Taklim Pendidikan Pasca TPQ Qiraati yang ada di YPI "Shidqul Amal" Kedungjaya betulbetul termasuk kategori lembaga pendidikan.

Terkait dengan penyelenggaraan pendidikan, Pemerintah RI telah mengeluarkan PP No 19 Tahun 2005 tentang SNP yang harus diikuti oleh semua penyelenggara pendidikan. Di dalam PP no 19 tahun 2005 itu disebutkan bahwa semua jenis, bentuk dan jenjang pendidikan harus memiliki 8 standard pendidikan, yaitu 1) Standar tingkat pencapean perkembangan; 2) Standar pendidik dan 3) tenaga kependidikan; 4) Standar isi, 5) proses dan penilaian; 6) Standar sarana dan prasarana, 7) pengelolaan, dan 8) pembiayaan. Karena itu sewajarnyalah bagi setiap lembaga kependidikan seharusnya mengacu pada PP no 19 tentang SNP itu.

System kependidikan atau kegiatan ngaji sore yang diselenggarakan oleh $\mathrm{KH}$ 
Abu Khaeruddin Thohir di Majlis Taklim Pendidikan Pasca TPQ Qiraati yang ada di YPI "Shidqul Amal" Kedung jaya sudah seharusnya dikelola secara institutional yaitu dilaksanakan dengan menggunakan system manajeman pendidikan dan mengikuti peraturan perundang-undangan yang berlaku di Indonesia.

\section{Pendekatan Penelitian}

Penelitian tentang pengelolaan kegiatan Ngaji Sore yang dilakukan oleh $\mathrm{KH}$ Abu Khaeruddin Thohir di Majlis Taklim Pendidikan Pasca TPQ Qiraati di YPI "Shidqul Amal" Kedungjaya ini, peneliti memilih menggunakan metode kualitatif. Karena peneliti melakukan pendekatan secara langsung terhadap obyek penelitian dan mengembangkannya menjadi konseptual dan kategoris. Data pene-litian yang diperoleh melalui pendekatan ini, berasal dari kondisi dan situasi yang sebenarnya, atau bukan dari laboratorium.

Karena sasaran dari penelitian ini adalah untuk mempelajari, menerangkan, atau menginterpretasi suatu kasus (case) pendidikan secara natural, maka dalam penelitian ini peneliti menggunakan penelitian studi kasus (Case Study Research [CSR]). Dasar dari penggunaan CSR adalah banyaknya peneliti yang memandang bahwa semua penelitian kualitatif adalah penelitian studi kasus; setiap obyek penelitian kualitatif adalah 'kasus', konsekwensinya. Dasar lainya adalah, CSR diartikan sebagai bentuk penelitian yang menggunakan analisis mendalam dari berbagai sudut pandang, dilakukan secara lengkap dan teliti terhadap seorang individu, keluarga, kelompok, lembaga, atau unit sosial lain. CSR juga dapat diartikan sebagai strategi dalam penelitian untuk mengungkap kasus tertentu. CSR memusatkan perhatian pada satu objek tertentu yang diangkat sebagai sebuah kasus untuk dikaji secara mendalam sehingga mampu membongkar realitas di balik fenomena. Data CSR dapat diperoleh dari semua pihak yang bersangkutan, baik melalui wawancara, observasi, partisipasi, dan dokumentasi. Data yang diperoleh dari berbagai cara itu, hakikatnya untuk saling melengkapi, walaupun ada kalanya data CSR yang diperoleh dari wawancara belum lengkap, sehingga harus dilalui dengan cara lain, seperti observasi, dan partisipasi.

Case Study Research (CSR) lebih menekankan pada kedalaman pemahaman terhadap masalah yang diteliti daripada banyaknya jumlah subjek yang diteliti. Karena itu, CSR dilakukan secara intensif, terperinci dan mendalam terhadap suatu fenomena dengan lingkup yang sempit. Kendati demikian, dimensi yang digali harus luas mencakup berbagai aspek hingga tidak ada satu pun aspek yang tertinggal.

Berdasarkan batasan-batasan tersebut di atas, dapat dipahami bahwa penelitian kualitatif Case Study Research (CSR) meliputi:

1. Sasaran penelitiannya dapat berupa manusia, peristiwa, latar, dan dokumen;

2. Sasaran-sasaran tersebut ditelaah secara mendalam sebagai suatu totalitas sesuai dengan latar atau konteksnya masing-masing dengan maksud untuk mernahami berbagai kaitan yang ada di antara variabelvariabelnya

Desain Penelitian. Keberadaan Majlis Taklim Pendidikan Pasca TPQ Qiraati di YPI "Shidqul Amal" Kedungjaya hingga tahun 2016 telah memperoleh respons atau tanggapan yang positif dari masyarakat desa sekitar. Kenyataan ini dapat dilihat dari setiap program kegiatan yang dirancang dan ditawarkan oleh pengelola Majlis Taklim Pendidikan Pasca TPQ Qiraati di YPI "Shidqul Amal" Kedung jaya selalu memperoleh sambutan baik, sehingga dalam waktu delapan tahun (2008-2016) ini beberapa lembaga pendidikan Islam yang ada di YPI "Shidqul Amal" Kedung jaya selalu memperoleh kepercayaan masyarakat luas yang menitipkan anaknya untuk dibimbing dan 
diajarkan membaca, menulis, menghafal dan tahsin al-Quran dengan menggunakan metode Qiraati.

Respons positif masyarakat sekitar Kecamatan Kedawung tidak hanya dalam bentuk kepercayaan menitipkan anakanaknya, akan tetapi mereka yang anakanaknya telah menyelesaikan jenjang pendidikan TKQ Qiraati dan telah menempuh pendidikan al-Quran selama dua tahun belajar pagi hari itu (07.45 s.d. 10.10), dititipkan kembali untuk diterima sebagai murid TPQ Qiraati yang waktu pembelajaranya setelah selesai belajar di SD yaitu pukul 14.00-17.30. Begitu juga dengan masyarakat yang anak-anaknya telah selesai dari TPQ Qiraati yang telah ditempuh selama lebih dari tiga tahun, agar melanjutkan pendidikannya sebagai murid di Pendidikan Pasca TPQ Qiraati yang waktu yang waktu belajarnya sore hari (ham 18.30 s/d 20.00). Bahkan ada beberapa remaja yang waktu siangnya sekolah di SMP/SMA, pada sore harinya mereka mengikuti sistem pembim-bingan dan pengajaran membaca, menulis, menghafal dan tahsin al-Quran dengan menggunakan metode Qiraati.

Mengapa masyarakat begitu merespon positif terhadap segala kegiatan yang dirancang dan diprogramkan oleh pengelola Majlis Taklim Pendidikan Pasca TPQ Qiraati di YPI "Shidqul Amal" Kedung jaya?

1. Karena dalam pembimbingan dan pengajaran baca tulis, hafal dan tahsin al-Quran dengan menggunakan metode Qiraati dikelola oleh sekelompok ustadz yang profesional dalam membelajarkan al-Quran, mereka secara sistematis, terstruktur dan teruji dalam menerapkan kurikulum pendidikan alQuran yaitu metode Qiraati (tertama bagi anak-anak usia sekolah mlalui TKQ dan TPQ).

2. Karena Pengelola Pendidikan Pasca TPQ yang ada di YPI "Shidqul Amal" Kedungjaya betul-betul menjalankan amanat atau kepercayaan orangtua yang telah menitipkan anak-anaknya; para ustadz selalu mencari cara agar santrinya itu merasa senang dan betah selama belajar di lingkungan YPI "Shidqul Amal" Kedungjaya. Kalau tidak senang dan betah, bagaimana mungkin anak-anak merasa sabar selama lima sampai tujuh tahun yaitu belajar di TKQ se-lama 1 tahun, belajar di TPQ selama 2-3 tahun dan belajar di MD selama 2-3 tahun).

3. Motivasi masyarakat yang sangat kuat dan mempercayakan anak-anaknya ke Pendidikan Pasca TPQ Qiraati yang ada di YPI "Shidqul Amal" Kedungjaya. Lebih dari itu, mereka yakin bahwa anak-anaknya akan memahami dan mengamalkan isi kandungan al-Quran yakni akhaqul karimah, sehingga anak-anak-nya kelak akan menjadi Generasi Qurani dan berakhlaqul karimah.

Pernyataan dan uraian di atas dapat diperhatikan pada gambar atau skema di bawah ini, yaitu sebagai berikut:

\section{PROGRM PENDIDIKAN YAYASAN PENDIDIKAN ISLAM "Shidqul}

1. Pendidikan TKQ Qiraati, Waktu Belajar Pagi ditempuh selama 1-2 tahun

2. Pendidikan TPQ Qiraati, Waktu Belajar Siang ditempuh selama 2-3 tahun

3. Majlis Taklim (MT) Qiraati, Waktu Belajar sore h ditempuh selama 2-3 tahun

4. Sekolah Dasar Al-Qur'an (SDQ) Qiraati Full Day, jam 14.00-17.10, ditempuh selama 6 tahun

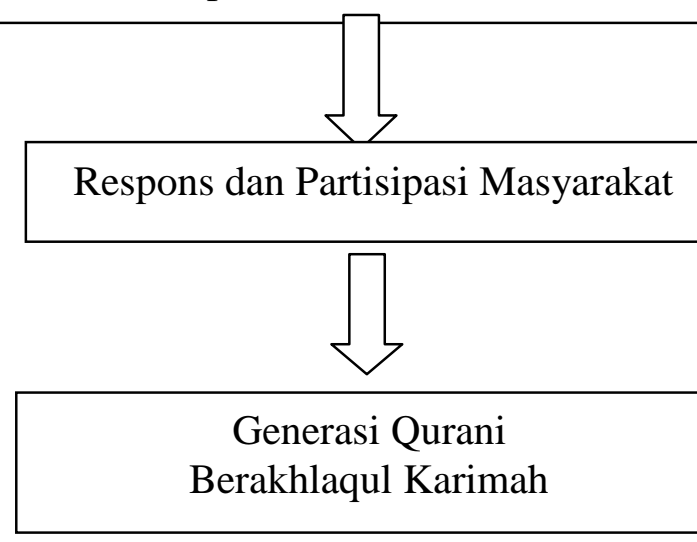


Data dan Sumber Data Penelitian. Secara umum, data dalam penelitian ini ada yang bersifat data teoritik dan data bersifat empirik. Data teoritik, yakni data yang diperoleh peneliti melalui kajian mendalam terhadap beberapa konsep dan teori yang berkaitan dengan respon dan par-tisipasi masyarakat terhadap kegiatan pendidikan keagamaan nonformal. Sedangkan data yang bersifat empirik, meru-pakan data yang diperoleh peneliti dengan melakukan penelitian secara langsung di lapangan, dengan cara pengamatan, wawancara mendalam kepada pengelola Majlis Taklim Pendidikan Pasca TPQ Qiraati, kepada masyarakat terutama orang tua yang anaknya belajar di Majlis Taklim Pendidikan Pasca TPQ Qiraati, tokoh masyarakat pada umumnya ataupun pengkajian terhadap dokumen yang ada di YPI "Shidqul Amal” Kedungjaya.

Yayasan Pendidikan Islam (YPI) "Shidqul 'Amal" yang berke-dudukan di desa Kedungjaya, pada awal berdirinya yakni tahun 2008. Pada tahun yang sama, keberadaan TKQ dan TPQ yang ada diakui, setelah memperoleh ijin operasional dari Kementrian Agama RI Kabupaten Cirebon. Saat itu lembaga pendidikan yang diajukan ke Kemenag RI Kabupaten Cirebon belum berbentuk YPI melainkan berupa lembaga pendidikan Pondok Pesantren yang secara khusus membelajarkan kepada masyarakat tentang membaca, menulis, menghafal dan tahsin al-Quran dengan menggunakan metode Qiraati. Sarana pendidikan yang saat itu digunakan untuk pembimbingan dan pembelajaran al-Quran adalah sebuah bangunan rumah yang sekaligus sebagai tempat tinggal kediaman keluarga $\mathrm{KH}$. Abu Khaeruddin Thohir.Walaupun sarana pendidikan yang masih sangat sederhana, KH Abu Khaeruddin Thohir telah mampu menyusun sebuah karya (setara syllabus) yang dijadikan sebagai panduan dan pedoman dalam mengelola pondok pesantren yang dirintisnya. Isi syllabus itu, meliputi Prinsip, Pedoman dan Amanah Pendidikan, Pengajaran al-Quran Metode Quraati.
Pada tahun 2000, ketika pemerintah mengeluarkan peraturan yang menyatakan bahwa setiap lembaga pendidikan harus berbadan hukum, maka berdasarkan AKTA NOTARIS NO. 200 SK. MEN-KUMHAM R.I TGL 16 NOPEMBER 2001 NO. C-506 HT.03.02-TH 2001SK. BAPERNAS TGL 13 - 10 - 2000 NOMOR 32 -XI - 2000 Pondok Pesantren "Shidqul Amal" berubah menjadi Yayasan Pendidikan Islam (YPI) "Shidqul Amal" yang berkedudukan di Desa Kedungjaya. Program pendidikan Islam yang tercantum di Yayasan Pendidikan Islam "Shidqul Amal" Kedungjaya itu adalah 1) Taman Kanak Kanak al-Quran (TKQ) Qiraati, 2) Taman Pendidikan al-Quran (TPQ) Qiraati, 3) Majlis Ta'lim (MT).

\section{Daftar Nama Pengasuh, Ustadz dan Staff Pendidikan Pasca TPQ Qiraati}

\section{YPI "Shidqul 'Amal” Kedungjaya Cirebon} tahun 2016

\begin{tabular}{|c|c|c|c|c|c|c|}
\hline $\begin{array}{l}\mathbf{N} \\
\mathbf{0}\end{array}$ & Nama & $\begin{array}{c}\text { Tmpa } \\
\text { t, } \\
\text { Tgl } \\
\text { Lahir }\end{array}$ & $\begin{array}{l}\text { Pen } \\
\text { didi } \\
\text { kan }\end{array}$ & $\begin{array}{c}\text { Jab } \\
\text { atan }\end{array}$ & $\begin{array}{l}\text { Mulai } \\
\text { Tugas }\end{array}$ & $\begin{array}{l}\text { Sya } \\
\text { had } \\
\text { ah }\end{array}$ \\
\hline 1 & $\begin{array}{c}\text { KH Abu } \\
\text { Khaeruddi } \\
n\end{array}$ & $\begin{array}{c}\text { Cirebo } \\
\mathrm{n}, \\
31-03- \\
1961\end{array}$ & S1 & $\begin{array}{c}\text { Pen } \\
\text { gasu } \\
\mathrm{h}\end{array}$ & 2015 & $\begin{array}{c}199 \\
3\end{array}$ \\
\hline 2 & $\begin{array}{c}\text { Ucu Hadi } \\
\text { Pamungka } \\
\text { s }\end{array}$ & $\begin{array}{c}\text { Cirebo } \\
n, \\
29-01- \\
1988\end{array}$ & D4 & $\begin{array}{c}\text { Kep } \\
\text { ala } \\
\text { MA } \\
\text { DIN }\end{array}$ & 2013 & $\begin{array}{c}201 \\
2\end{array}$ \\
\hline 3 & $\begin{array}{l}\text { Mizan } \\
\text { Fadhil }\end{array}$ & $\begin{array}{c}\text { Cirebo } \\
n, \\
25-10- \\
1992\end{array}$ & $\begin{array}{c}\text { SLT } \\
\text { A }\end{array}$ & $\begin{array}{c}\text { Wak } \\
\text { a } \\
\text { MA } \\
\text { DIN }\end{array}$ & 2013 & $\begin{array}{c}201 \\
1\end{array}$ \\
\hline 4 & $\begin{array}{l}\text { M Jumadil } \\
\text { Kubro }\end{array}$ & $\begin{array}{c}\text { Kebu } \\
\text { men, } \\
01-04- \\
1981\end{array}$ & $\begin{array}{c}\text { SLT } \\
\text { A }\end{array}$ & $\begin{array}{c}\text { Usta } \\
\mathrm{dz}\end{array}$ & 2018 & $\begin{array}{c}200 \\
4\end{array}$ \\
\hline 5 & $\begin{array}{l}\text { Abdul } \\
\text { Aziz } \\
\text { Furqon }\end{array}$ & $\begin{array}{c}\text { Suban } \\
\mathrm{g}, \\
25-05- \\
1982\end{array}$ & S1 & $\begin{array}{c}\text { Usta } \\
\mathrm{dz}\end{array}$ & 2014 & $\begin{array}{c}200 \\
8\end{array}$ \\
\hline 6 & $\begin{array}{c}\text { Abdurrohi } \\
\mathrm{m}\end{array}$ & $\begin{array}{c}\text { Cirebo } \\
\text { n, } \\
01-02- \\
1993\end{array}$ & $\begin{array}{c}\text { SLT } \\
\text { A }\end{array}$ & $\begin{array}{c}\text { Usta } \\
\mathrm{dz}\end{array}$ & 2011 & $\begin{array}{c}201 \\
1\end{array}$ \\
\hline 7 & $\begin{array}{c}\text { Tulus } \\
\text { Setiadi }\end{array}$ & $\begin{array}{c}\text { Kebu } \\
\text { men, } \\
18-12- \\
1089\end{array}$ & $\begin{array}{c}\text { SLT } \\
\text { A }\end{array}$ & $\begin{array}{c}\text { Usta } \\
\mathrm{dz}\end{array}$ & 2011 & $\begin{array}{c}201 \\
1\end{array}$ \\
\hline 8 & Al-Gufron & $\begin{array}{c}\text { Cirebo } \\
\mathrm{n}, \\
15-10-\end{array}$ & $\begin{array}{c}\text { SLT } \\
\text { A }\end{array}$ & $\begin{array}{c}\text { Usta } \\
\mathrm{dz}\end{array}$ & 2009 & $\begin{array}{c}200 \\
8\end{array}$ \\
\hline
\end{tabular}




\begin{tabular}{|c|c|c|c|c|c|c|}
\hline & & 1986 & & & & \\
\hline 9 & $\begin{array}{c}\text { A. } \\
\text { Sudirman }\end{array}$ & $\begin{array}{c}\text { Cirebo } \\
\text { n, } \\
01-10- \\
1994\end{array}$ & $\begin{array}{c}\text { SLT } \\
\text { A }\end{array}$ & $\begin{array}{c}\text { Usta } \\
\mathrm{dz}\end{array}$ & 2015 & $\begin{array}{c}201 \\
4\end{array}$ \\
\hline 10 & $\begin{array}{c}\text { Nurul } \\
\text { Alim }\end{array}$ & $\begin{array}{c}\text { Cirebo } \\
\text { n, } \\
01-04- \\
1995\end{array}$ & $\begin{array}{c}\text { SLT } \\
\text { A }\end{array}$ & $\begin{array}{c}\text { Usta } \\
\text { dz }\end{array}$ & 2016 & $\begin{array}{c}201 \\
4\end{array}$ \\
\hline 11 & Sa'adah & $\begin{array}{c}\text { Cirebo } \\
\text { n, } \\
23-06- \\
1973\end{array}$ & S1 & $\begin{array}{c}\text { Usta } \\
\text { dz }\end{array}$ & 2015 & $\begin{array}{c}201 \\
5\end{array}$ \\
\hline 12 & $\begin{array}{l}\text { Muqoyyi } \\
\text { m }\end{array}$ & $\begin{array}{c}\text { Cirebo } \\
\text { n, } \\
03-01- \\
1986\end{array}$ & $\begin{array}{c}\text { SLT } \\
\text { A }\end{array}$ & $\begin{array}{c}\text { Usta } \\
\text { dz }\end{array}$ & 2014 & \\
\hline 13 & $\begin{array}{c}\text { A. Kamal } \\
\text { Bashori }\end{array}$ & $\begin{array}{c}\text { Brebe } \\
\text { s, } \\
02-08- \\
1992\end{array}$ & $\begin{array}{c}\text { SLT } \\
\text { A }\end{array}$ & $\begin{array}{c}\text { Tata } \\
\text { Usa } \\
\text { ha }\end{array}$ & 2016 & \\
\hline
\end{tabular}

Dokumen YPI Shidqul Amal Kedung Jaya, 2016

Teknik Pengumpulan Data. Teknik pengumpulan data yang utama penelitan kualititatif menurut Bungin (2007:110) adalah wawancara mendalam (indepth interview) yang dibantu dengan pedoman wawancara, mempelajari dokumen serta observasi dan pengamatan secara langsung juga dilakukan Focus Group Discussion (FGD).

Teknik Analisis Data. Teknik analisis data dalam penelitian kualitatif dida-sarkan pada pendekatan studi kasus, yaitu: a. Mengorganisir informasi, b. Membaca keseluruhan informasi dan memberi kode, c. Membuat suatu uraian terperinci mengenai kasus dan konteksnya, d. Peneliti menetapkan pola dan mencari hubungan antara beberapa kategori, e. Selanjutnya peneliti melakukan interpretasi dan mengembangkan generalisasi natural dari kasus baik untuk peneliti maupun untuk penerapannya pada kasus yang lain, dan $\mathrm{f}$. Menyajikan secara naratif

Dalam pelaksanaannya, teknik analisis data yang dilakukan peneliti untuk menyusun dan menggolong-golongkan data ke dalam bentuk yang disesuaikan dengan fokus penelitian. Sedangkan data yang diperoleh dalam penelitian ini adalah data kualitatif yang berbentuk kata verbal atau kalimat yang panjang dan bahkan mungkin pendek. Namun dari data yang beraneka ragam itu, dalam penelitian kualitatif, analisisnya sudah dimulai sejak awal dimulainya penelitian. Data hasil dari penelitian, kemudian segera ditulis dalam catatan lapangan dan dianalisis. Dengan demikan, analisis data adalah suatu proses untuk menyusun, menggolongkan dan mengkategorikan data guna mencari pola atau tema dengan maksud untuk memahami makna data. Beberapa langkah dalam menganalisa data, yaitu: 1) Reduksi data, 2) Display atau penyajian data; 3) Mengambil atau penarikan kesimpulan dan verifikasi (Nasution, 1988:128-130).

Reduksi data adalah proses pemilahan, pemusatan perhatian untuk menyingkat dan menyederhanakan data dalam bentuk uraian atau laporan yang rinci dan sistematis, dengan menonjolkan pokokpokok masalah yang penting agar mudah dikendalikan. Reduksi data merupakan suatu bentuk penajaman, penggolongan dan pembuangan data yang dianggap tidak perlu, sehingga data tersebut akan memberikan gambaran terarah tentang hasil pengamatan. Display data adalah upaya penyajian data untuk melihat gambaran keseluruhan atau sebagian data hasil dari penelitian. Informasi-informasi yang diperoleh setelah direduksi, kemudian disusun dalam suatu bentuk tertentu sehingga mudah dilihat atau dimanfaatkan peneliti. Display data dilakukan, agar peneliti terhindar dari tumpukan data. Sedangkan penarikan kesimpulan dan verifikasi adalah upaya untuk mencari garis baru mak-na terhadap data yang terkumpul, dengan cara mencari suatu pola, tema hubungan serta persamaan terhadap hal-hal yang muncul. Mungkin kesimpulan pertama masih bersifat sementara dan kabur atau samar-samar, namun dengan bertambahnya data yang diperoleh, kesimpulan yang mantap peneliti harus senantiasa memverifikasi data yang masuk selama penelitian berlangsung.

Dengan demikian, reduksi data dan penyajian data serta pena-rikan kesimpulan 
merupakan proses yang saling kait mengait dalam pengumpulan data. Langkah yang demikian dilakukan sejak awal penelitian, sehingga diharapkan dapat diperoleh temuan yang dapat dipertanggung jawabkan.

Tempat Penelitian. Penelitian ini dilakukan di lembaga pendidikan berkaitan dengan pengelolaan Majlis Taklim Pendidikan Pasca TPQ Qiraati di YPI "Shidqul Amal" Kedungjaya, karena itu Qualitative research sangat cocok dilakukan pada persoalan-persoalan kemasyarakatan yang ada di wilayah keagamaan dan institusi keagamaan.

Daftar Ustadz dan Kegiatan Ngaji Sore di Masjlis Taklim Pendidikan Pasca TPQ

Qiraati YPI “Shidqul Amal” Kedungjaya Tahun 2016

\begin{tabular}{|c|l|l|l|}
\hline $\begin{array}{c}\text { N } \\
\mathbf{0}\end{array}$ & N a m a & $\begin{array}{l}\text { Program/Kela } \\
\text { s }\end{array}$ & Murid \\
\hline 1 & $\begin{array}{l}\text { Ahmad } \\
\text { Sudirman }\end{array}$ & Qiraati jilid 1 & $\begin{array}{l}\text { Anak } \\
\text { usia 6 } \\
\text { tahun } \\
\text { ke atas }\end{array}$ \\
\hline 2 & $\begin{array}{l}\text { Tulus } \\
\text { Setiadi }\end{array}$ & Qiraati jilid 2 & $\begin{array}{l}\text { Anak } \\
\text { usia 6 } \\
\text { tahun } \\
\text { ke atas }\end{array}$ \\
\hline 3 & Nurul Alim & Qiraati jilid 3 & $\begin{array}{l}\text { Anak } \\
\text { usia 6 } \\
\text { th ke } \\
\text { atas }\end{array}$ \\
\hline 4 & $\begin{array}{l}\text { Abdul Aziz } \\
\text { Furqon }\end{array}$ & $\begin{array}{l}\text { Tadarrus Al- } \\
\text { uran }\end{array}$ & $\begin{array}{l}\text { Dewas } \\
\text { a }\end{array}$ \\
\hline 5 & $\begin{array}{l}\text { Abdurrohi } \\
\text { m }\end{array}$ & $\begin{array}{l}\text { Tahfidz } \\
\text { Quran }\end{array}$ & $\begin{array}{l}\text { Alumn } \\
\text { i TPQ }\end{array}$ \\
\hline 6 & $\begin{array}{l}\text { Mizan } \\
\text { Fadhil }\end{array}$ & Diniyah & $\begin{array}{l}\text { Alumn } \\
\text { i TPQ }\end{array}$ \\
\hline 7 & Muqoyyim & Diniyah & $\begin{array}{l}\text { Alumn } \\
\text { i TPQ }\end{array}$ \\
\hline 8 & Sa'adah & Diniyah & $\begin{array}{l}\text { Alumn } \\
\text { i TPQ }\end{array}$ \\
\hline
\end{tabular}

Dokumen YPI Shidqul Amal Kedung Jaya, 2016

Ada beberapa alasan yang kuat dan pentingnya penelitian kualitatif di lakukan pada lembaga pendidikan, di antaranya adalah:

a. Pendidikan sebagai proses sosialisasi pada hakikatnya adalah interaksi manusia dengan lingkungan yang membentuknya melalui proses belajar dalam konteks lingkungan yang berubah-ubah

b. Pendidikan selalu melibatkan komponen manusia, yakni tenaga pendidik, tenaga kependidikan dan peserta didik. Setiap kom-ponen berinteraksi satu sama lain dalam suatu proses pendidikan dan pengajaran untuk mencapai tujuan pendidikan ataupun tujuan pembelajaran yang telah ditetapkan;

c. Pendidikan sebagai suatu sistem tidak hanya berorientasi kepada hasil, tetapi juga berorientasi kepada proses agar memperoleh hasil yang optimal;

d. Tekanan utama pendidikan adalah pembinaan dan pengembangan kepribadian manusia mencakup aspek intelektual, moral, sosial dalam satu kesatuan utuh, serasi, selaras, dan seimbang.

Penggunaan penelitian kualitatif yang dilaksanakan di Majlis Taklim Pendi-dikan Pasca TPQ Qiraati YPI "Shidqul Amal" Kedung jaya yakni bertujuan untuk mengetahui sistem pengelolaan pendi-dikan Islam yang dilaksanakan di Majlis Taklim Pendidikan Pasca TPQ Qiraati YPI "Shidqul Amal" Kedungjaya sebagai lembaga pendidikan Islam yang dalam pembelajarannya berorientasi pada internalisasi nilai-nilai keagamaan. Dalam pelaksanaannya peneliti berupaya untuk;

a. Mendeskripsikan proses pendidikan berdasarkan apa yang terjadi di beberapa lembaga pendidikan yang ada di YPI "Shidqul "Amal" Kedungjaya, 
sebagai bahan kajian lebih lanjut untuk me-nemukan kekurangan dan kelemahan, sehingga dapat ditentukan upaya penyempurnaannya.

b. Menganalisis dan menafsirkan suatu fakta, gejala dan penge-lolaan pendidikan yang terjadi di Majlis Taklim Pendidikan Pasca TPQ Qiraati di YPI "Shidqul Amal" Kedungjaya. Dengan demikian, qualitative research ini termasuk jenis penelitian studi kasus yaitu penelitan yang berangkat dari kasus tertentu berda-sarkan pada pengalaman nyata dari ungkapan atau perilaku obyek peneliti atau situasi lapangan.

Pembahatasan terhadap obyek penelitian ini, peneliti menen-tukan sendiri yaitu kegiatan ngaji sore di Majlis Taklim Pendidikan Pasca TPQ Qiraati di YPI "Shidqul Amal" Kedungjaya. Teknik penentuan obyek penelitian ini menurut Sugiono (2007:78) disebut teknik sampling purposif yaitu teknik penentuan yang didasarkan pada pertimbanganpertimbangan tertentu.

\section{E. Hasil Penelitian}

1. Kegitaan yang dilakukan KH. Abu Khaeruddin Thohir di Yayasan Pendidikan Islam "Shidqul Amal" Kedungjaya.

Pada 2008 kegiatan yang dilakukan $\mathrm{KH}$ Abu Khaeruddin Thahir, masih sangat sederhana yaitu membimbing, mengajarkan baca tulis, hafalan dan tashhih alQuran dengan menggunakan metode Qiraati, bertempat di rumahnya. Setelah memperoleh ijin dari Kementrian Agama Kabupaten Cirebon, dilaksanakanlah system pendidikan TKQ dan TPQ dengan menggunakan metode Qiraati secara terprogram, terstruktur, terencana dan dilaksanakan juga evaluasi (tash-hih). Tahun 2009, setelah ada "alumni", KH Abu
Khaeruddin Thohir membe-rikan kesempatan kepada para alumni untuk mengikuti kegiatan ngaji sore di Majlis Taklim waktu belajarnya sore hari yakni jam 18.30 s.d. 20.30). Program yang diselenggarakan oleh Pendidikan Pasca TPQ Qiraati melalui Majlis Taklim ini, setiap tahun selalu bertambah. Pada 2015-2016, Pendi-dikan Pasca TPQ meliputi: Kelas Qiraati jilid 1, 2, 3 (anak usia SD/MI); Baca, tulis dan tahfidz Al-Quran (orang dewasa, usia 17 th ke atas); Diniyah (para alumni). Materi yang disampaikan meliputi: tashhih al-Quran, majmuatid-durus meliputi Aqidah, Akhlaq, Fiqh, Tarikh dan Ilmu Tajwid.

2. Respon masyarakat terhadap pengelolaan kegiatan Ngaji Sore di Majlis Taklim Pendidikan Pasca TPQ Qiraati YPI "Shidqul Amal" Kedungjaya.

Pada 2008, ketika kegiatan KH Abu Khaeruddin Thahir, masih sangat sederhana masyarakat belum banyak merespon. Respon positif masyarakat meluas, ketika berdiri TKQ dan TPQ Qiraati. Respon positif masyarakat semakin meluas, ketika tahun 2009 KH. Abu Khaeruddin Thohir menawarkan program ngaji sore. Program ini disampaikan kepada masyarakat yang anaknya telah lulus dan mengikuti prosesi wisuda di TPQ Qiraati yang diselenggarakan oleh YPI "Shidqul Amal" Kedungjaya. Mereka akan ditempatkan menjadi murid pendidikan Pasca TPQ, yang waktu bela-jarnya sore hari yaitu dari jam 18.30 s.d. 20.15. Karena itu, pengelola pendidikan Pasca TPQ Qira-ati dikhusukan bagi para alumni/lulusan dari TPQ Qiraati. Mereka yang mengikuti kegiatan ngaji sore (Pendidikan 
Pasca TPQ Qiraati) ini akan dibimbing oleh seorang ustadz dengan jumlah muridnya tidak lebih dari 16 orang.

Pada tahun 2016 juga, KH Abu Kharuddin Thohir memberikan kesempatan kepada masya-rakat yang anaknya sudah remaja/dewasa tetapi belum pernah mengikuti pembelajaran alQuran dengan menggunakan metode Qiraati, diajak untuk ikut serta menjadi murid di pendidikan Pasca TPQ Qiraati yang waktu belajarnya sore hari. Ajakan $\mathrm{KH}$ Abu Khaeruddin Thohir ini mendapat respon positif, sehingga saat itu juga beberapa remaja dan orang dewasa men-daftarkan diri menjadi murid dalam kegiatan sore. Mereka akan dibimbing dan dibina pengajaran al-Quran dengan metode Qiraati oleh ustadz melalui program pengajian alQuran.

Program-program yang ditawarkan oleh KH. Abu Khaeruddin Thohir sebagai Pengasuh YPI "Shidqul Amal" Kedungjaya, selalu disambut baik dan masyarakat mengikutinya dengan antusiasme. Di bawah ini adalah program yang sesungguhnya di luar system pendidikan TKQ Qiraati dan pendidikan TPQ Qiraati. Tahun 2016 ini, pengelola Pendidikan Pasca TPQ Qiraati memberikan kesem-patan kepada masyarakat untuk mengikuti pembelajaran alQuran metode Qiraati. Mereka akan diklasifikasi sebagai murid ngaji sore melalui program Qiraati jilid 1, jilid 2 dan jilid 3. Program ini dibuka, karena saking banyaknya masyarakat yang anaknya belum pernah mengikuti pendidikan TKQ Qiraati dan TPQ Qiraati, tetapi mereka berkeinginan agar anaknya memperoleh pembimbingan dan peng-ajaran baca, tulis, hafal alQuran metode Qiraati di YPI "Shidqul Amal" Kedung jaya.

3. Partisipasi masyarakat terhadap pengelolaan kegiatan Ngaji Soredi Majlis Taklim Pendidikan Pasca TPQ Qiraati di YPI "Shidqul Amal" Kedungjaya.

Paling tidak ada empat bentuk partisipasi yang dilakukan masyarakat, sehingga kegiatan ngaji sore di Majlis Taklim Pendidikan Pasca TPQ Qiraati semakin berkembang. Keempat bentuk partisipasi itu adalah sebagai berikut:

a. Partisipasi Berbentuk Bakti sosial. Bentuk partisipasi seperti ini masyarakat selalu memberikan bantuan secara suka rela (tidak menuntut bayaran) ketika lembaga melakukan pekerjaan/ pembangunan sarana belajar atau pengecatan marka jalan raya, pagar pembatas. Hanya saja aksi sosial bersifat sukarela seperti ini baiknya dikelola secara terorganisasi, agar supaya jalinan kerja sama yang sudah baik ini tidak ada yang dirugikan demi membantu lembaga. Perlu adanya seseorang yang dijadikan sebagai penggerak, dalam hal ini bisa jadi seseorang yang berpengaruh di masyarakat setempat untuk menjadi motivator terhadap masyarakat agar aksi masal di dalam mengerjakan proyek dapat terselenggara dengan baik.

b. Partisipasi Berbentuk Ide atau Gagasan. Bentuk partisipasi masyarakat dalam bentuk ide atau gagasan ini 
masih belum maksimal, ini dapat dibuktikan dari sistem pengelolaan Majlis Taklim terutama dalam pengadaan sarana dan prasaranan belajar masih belum maksimal. Padahal dengan adanya ide atau gagasan yang diharapkan orangtua atau masyarakat, akan bermunculan hasil pemikiran yang lebih luas dan dapat dijadikan bahan pertimbangan oleh pihak penyelenggara pendidikan.

c. Partisipasi Berbentuk Uang atau Barang. Dalam hal ini paling tidak ada dua bentuk partisipasi yaitu partisipasi bersifat spotan dan partisipasi yang telah direncanakan. Partisipasi yang bersifat spontan, seringkali dilakukan masyarakat ketika lembaga pendidikan melak-sanakan program incidental. Sedangkan partisipasi yang ber-sifat terencana antara lain, ketika lembaga berencana melengkapi atau memperbaiki sarana fasilitas lembaga, memperbaiki pagar pembatas antara lembaga dengan jalan umum, melakukan pelatihan terhadap pendidik atau tenaga kependidikan.

d. Partisipasi Berbentuk Keterampilan. Partisipasi dalam bentuk berbagi keterampilan dan keahlian yang dimiliki masyarakat terhadap kegiatan ngaji sore di Majlis Taklim, belum banyak terlihat. Kenyataan ini terjadi, karena sistem pendidikan dan pembelajaran yang berlangsung di Majlis Taklim Pendidikan Pasca TPQ Qiraati, tidak memungkinkan bantuan dari masyarakat. Sebab, untuk menjadi tenaga

kepedidikan atau tenaga
pendidikan dibutuhkan
persyaratan akademik secara
prosedural dan terstruktur.

\section{F. Kesimpuan}

Respon dan Partisipasi Masyarakat terhadap Pengelolaan Pen-didikan Islam Nonformal di Majlis Taklim Pendidikan Pasca TPQ Qiraati YPI "Shidqul Amal" Kedungjaya.

1. Respon masyarakat secara meluas sangat positif, terhadap kegiatan yang diselenggarakan oleh Majlis taklim Pendi-dikan Pasca TPQ Qiraati, walaupun belajarnya sore hari. Masyarakat yang menitipkan anaknya untuk mengikuti kegiatan ngaji sore di Majlis Taklim Pendidikan Pasca TPQ Qiraati datang dari wilayah Kecamatan Talun dan Kecamatan Sumber. Apalagi pengelola kegiatan ngaji sore membuka "kelas sore" bagi anak yang belum pernah belajar di TKQ dan TPQ Qiraati, melalui program/kelas Qiraati jilid 1, 2 dan 3.

2. Partisipasi yang dilakukan masyarakat sangat bermanfaat, sehingga kegiatan di Majlis Taklim Pendidikan Pasca TPQ Qiraati semakin berkembang. Bentuk partisipasi itu meliputi: a. Partisipasi Berbentuk Bakti sosial, b. Partisipasi Berbentuk ide/gagasan, c. Partisipasi Berbentuk Uang/ Barang, d. Partisipasi Berbentuk Tenaga Sukarela, e. Partisipasi Berbentuk Keterampilan

\section{G. Daftar Pustaka}

Abu Huraerah, 2008, Pengorganisasian dan Pengembangan Masya-rakat Model dan Strategi Pembangunan Berbasis Kerakyatan, Bandung: Humaniora 
Ahmad Subandi, 1982, Psikologi Sosial, Jakarta: Bulan Bintang, 1982

Agus Sujanto, 2004, Psikologi Umum. Jakarta: Bumi Aksara.

Bimo Walsito, 1999, Psikologi Umum, Yogyakarta: UGM

Jalaludin Rahmat, 1999, Psikologi Komunikasi, Bandung: Remaja Rosda karya.

Lexy J. Moleong, 2006 Metodologi Penelitian Kualitatif, Bandung: Rosda Karya,

Matthew B. Miles, A. Michel Huberman, 2009, Analisis Data Kualitatif: Buku Sumber tentang Metode-Metode Baru, Terj. Tjetjep Rohendi Rohidi (Jakarta: UI Press,

Moh. Nazir, 1988, Metode Penelitian, Cet. 3, Ghalia Indonesia,

Noeng Muhadjir, 1998, Metodologi Penelitian Kua-litatif, Yogya-karta: Bayu Indra Grafika,

Peraturan Pemerintah (PP) Nomor 17 Tahun 2010 tentang Pengelolaan dan Penyelenggaraan Pendidikan

Peraturan Pemerintah (PP) Nomor 19 Tahun 2005 tentang Standar Nasional Pendidikan

Poerwadarminta, $\quad 1999, \quad$ Psikologi Komunikasi, Jakarta: Universitas Terbuka (UT)

Purwanto, Ngalim. 1991. Administrasi dan Supervisi Pendidikan, Bandung: PT Remaja Rosda karya

Robert K. Yin, 2002, Studi Kasus Desai dan Metode, Ter. M. Djauji Mudzakir, Jakarta: Raja Grafindo Persada,.

Sagala, Syaiful. 2009. Administrasi Pendidikan, Bandung : ALFA-BETA

Soenarjo dan Djoenarsih S. Soenajo, 1983, Himpunan Istilah Komunikasi, Yogyakarta: Liberty.
Terry, R, George, 2014, Guide to Management (Prinsip-prinsip Manajemen) Terj, J. Smith D.F.M, , Bumi Aksara, Jakarta:

Trianto, 2011, Desain Pengembangan Pembelajaran Tematik bagi Anak Usia Dini, TK/RA dan Anak Usia kelas awal SD/MI, Kencana Predina Prenada Media Group, Jakarta,

Usman, Husaini, 2006, Manajemen Teori, Praktik, dan Riset Pendidikan, Bumi Aksara. Jakarta:.

Undang Undang RI nomor 20 tahun 2003 tentang Sistem Pendidikan Naional, Jakarta

Undang Undang RI nomor 14 tahun 2005 tentang Guru dan Dosen 